\title{
Assessment of all groups of animal remains in sediments should precede special investigation of particular groups
}

\begin{abstract}
N.N. Smirnov
A.N. Severtsov Institute of Ecology and Evolution, Russian Academy of Sciences, Leninsky prospect 33, Moscow119071 Russia.E-mail:smirnov08520@mail.ru

ABSTRACT: Remarkably, animal remains in lake sediments represent the entire integrated zoocenosis, as far as its constituents leave skeletal fragments. Recording of all present groups and their quantification are important points in such method. In the absence of general representation of relative importance of all groups, it is impossible to determine to which zoocoenosis the excellent special studies fit in, made, e.g., on cladocerans, chironomids, etc.

How to cite this article: Smirnov N.N. 2018. Assessment of all groups of animal remains in sediments should precede special investigation of particular groups // Invert. Zool. Vol.15. No.3. P.225-229. doi: 10.15298/invertzool.15.3.02
\end{abstract}

KEY WORDS: palaeolimnology, zoological analysis, bottom sediments.

\section{Групповой анализ остатков животных в донных отложениях должен предшествовать исследованиям отдельных групп}

\section{Н.Н. Смирнов}

Институт проблем экологии и эволюиии им. А.Н. Севериова РАН, Ленинский прт. 33, Москва 119071, Россия. E-mail: smirnov08520@mail.ru

РЕЗЮМЕ: Примечательно, что зоологические остатки в озерных отложениях несут информацию обо всем зооценозе водоемов, поскольку многие компоненты зооценоза представлены в отложениях скелетными фрагментами. Инвентаризация всех групп животных и оценка их обилия является важным этапом зоологического анализа донных отложений. В отсутствие общего представления об относительном обилии всех групп, невозможно определить, какой метод более подходит для исследования данных отложений: кладоцерный, хирономидный, или какой-либо другой. Как цитировать эту статью: Smirnov N.N. 2018. Assessment of all groups of animal remains in sediments should precede special investigation of particular groups // Invert. Zool. Vol.15. No.3. P.225-229. doi: 10.15298/invertzool.15.3.02

КЛЮЧЕВЫЕ СЛОВА: палеолимнология, зоологический анализ, донные отложения. 
Remarkably, animal remains in lake sediments represent the entire integrated zoocenosis, as far as its constituents leave skeletal fragments. In contrast, information on living groups of the fauna can hardly be transformed in a model wholly representing the type of zoocenosis or the biological type of a water body (Smirnov, 1984, 2010).

Particular groups of subfossil fauna present in sediments are now extensively studied cladocerans (Hofmann, 2000; Sarmaja-Korjonen, 2002; Szeroczyñska, Sarmaja-Korjonen, 2007; Korovi, Smol, 2012; Kirillova et al., 2016), chironomid larvae (Nazarova et al., 2013, 2015), sponges (Harrison, 1998) and some others being most prominent. However, few authors since Korde $(1960,1968)$ estimated the relative ratios of all particular faunal groups in the whole thanatocoenosis, e.g., as relative percentages. Still, there is reason for such an integrated approach as, e.g., the Cladocera may be not only abundant but also rare or absent in the biocoenoses or at some stage of its development. For example, Cladocera remains seem to be absent in Lake Van (Turkey) but ostracods dominant (Smirnov, 1984). It is known that in highly alkaline waters there will be no diatom remains, and in acid waters, no ostracods (Smirnov, 2010).

Recording of all present groups and their quantification are important points in such method. In the absence of general representation of relative importance of all groups, it is impossible to determine to which zoocoenosis the excellent special studies fit in, made, e. g., on cladocerans, chironomids, etc.

An example of the aforementioned method is a $5.45 \mathrm{~m}$ core from Lake Tulubaevo, Tyumen region, Western Siberia, Russia (Fig. 1) examined by Korde (1960). In the right half of the figure the formation of zoocoenosis is shown $v s$. algae in the left side. Formation of the zoocoenosis began from complete domination of sponges followed by complete domination of ostracods in the absence of the Cladocera. Cladocera appeared later, accompanied by a low percentage of insects, and reached domination. Some testates also were present in the later period. The animal coenosis developed against the initial presence of diatoms and gradual development of blue-greens and protococcous algae.

My own data on a $180 \mathrm{~cm}$ core from Lake Dund-Nur (Mongolia) demonstrated that the initial dominance of Cladocera may decrease and be followed by abundant development of sponges (Smirnov, 2010).

On the basis of the data obtained principally by Korde (1960), four types of zoothanatocoenoses may be distinguished differing in domination of a particular group of invertebrates: those with domination of Cladocera, ostracods, sponges, and (rarely) testacids. Recently, one more potential dominant group is added tintinnids (Smirnov et al., 2013, see Fig. 2).

The first three types are shown in the diagram for Lake Tulubaevo, in sequence from the beginning (from the bottom of the drawing): sponges, ostracods, Cladocera. Domination of testacids was recorded in Lake Krugloe, with maximum at $2.5 \mathrm{~m}$ (Korde, 1960), Lake Glubokoe at $55 \mathrm{~cm}$ (Sapelko et al., 2013) (both in the Moscow region, Russia).

Cladocera are usually dominant in sediments of lakes in temperate latitudes. Domination of ostracods is observed in Lake Van, of sponges in Lake Baikal (Karabanov et al., 2000). Though cladocerans may be completely absent, mostly they are frequent and abundant. Usually, from 10 to 30 species are recorded in the sediments. The extreme case is Lake Sevan (Armenia), with one abundant cladoceran in sediments of its open part - Daphnia hyalina, with very few Chydorus fragments and no Bosmina (Smirnov, 1999).

As to the cladoceran part of the thanatocoenosis, the domination of the following taxa was recorded: Bosmina, or Chydorus, or Daphnia, or littoral cladocerans. Again, each of them may be almost or completely absent. Examples are:

Bosmina - domination in Lake Onego (Smirnov, 1984), absence in Lake Sevan, Lake Kotokel (Korde, 1968);

Chydorus - domination in Lake Kotokel, very inhibited in Lake Sevan, Lake Onego; 


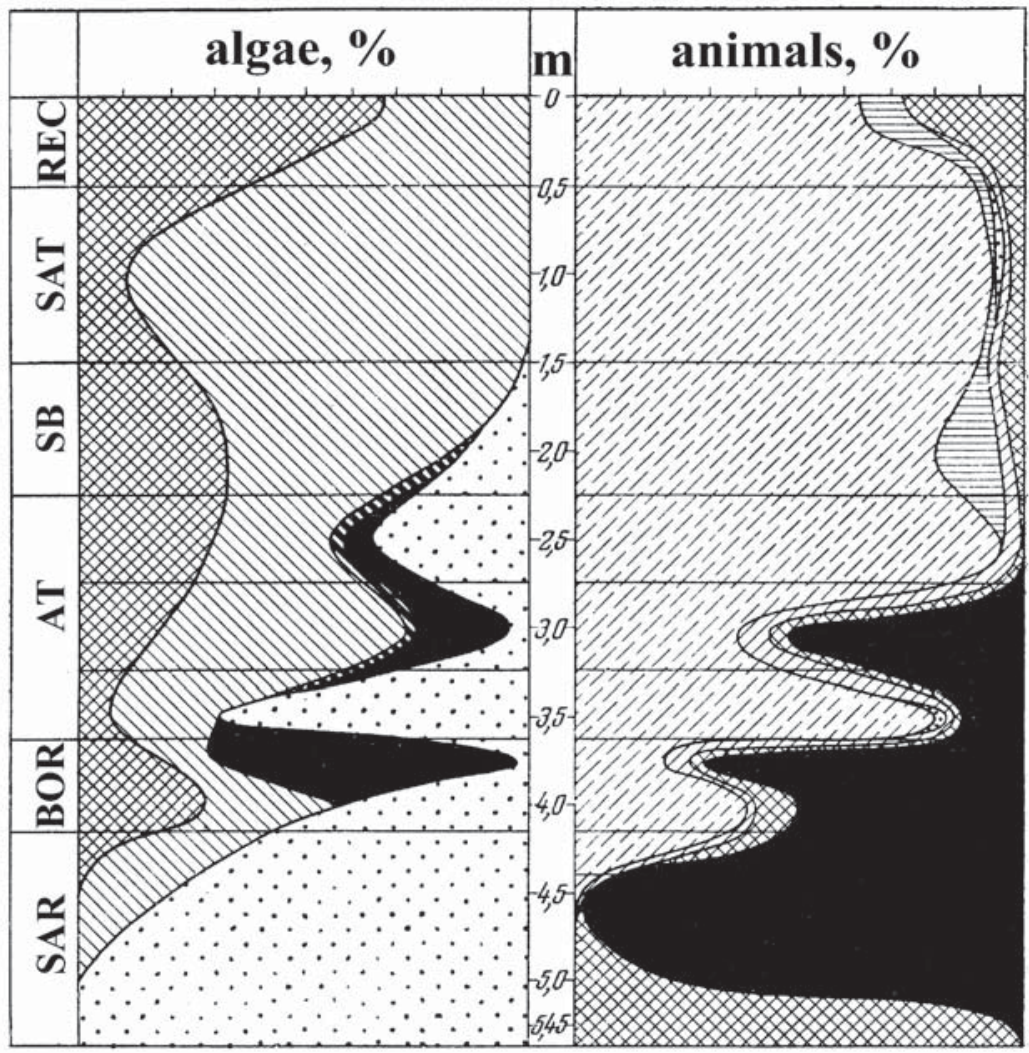

Algae

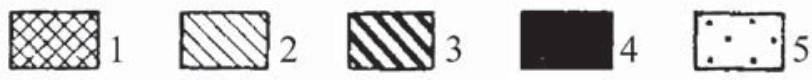

Animals
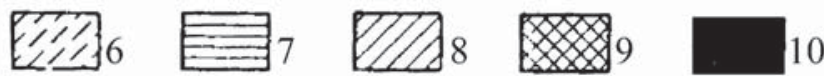

Fig. 1. Formation of algothanaocoenosis (leftt) and zoothanatocoenosis (right) of Lake Tulubaevo. It is clearly demonstrated that the initial domination of sponges is followed by domination of ostracods and then by Cladocera. The relative role of Cladocera is different in different periods. Domination of diatoms is followed by an increasing role of green algae and then by that of blue-greens. Isolated treatment of, e.g., Cladocera, would not show these changes. Abbreviations for chronozones of Holocene: SAR - Sarmat; BOR - Boreal; AT - Atlantic; SB - Subboreal; SAT - Subatlantic; REC — Recent. Legend for subfossil remains: 1 - Cyanobacteria; 2 - Protococcophyceae; 3 - Desmidiales; 4 - Chrysomonadina; 5 Bacillariophyceae; 6 - Cladocera; 7 - Protozoa; 8 - Insecta; 9 - Porifera; 10 - Ostracoda. After Korde (1960).

Рис. 1. Формирование альготанатоценоза (слева) и зоотананоценоза (справа) Озера Тулубаево. Графики четко демонстрируют, что изначальное доминирование губок сменилось на доминирование остракод, потом - кладоцер. Относительная роль Cladocera различна в различные периоды времени. Период доминирования диатомовых водорослей сменился периодом увеличения зеленых, потом цианобактерий. Изолированный анализ Cladocera не выявит данные изменения. Аббревиатуры периодов голоцена: SAR - сармат; BOR - бореал; AT — атлантик; SB — суббореал; SAT субатлантик; REC — современность. Обозначения для групп животных и растений: 1 - Cyanobacteria; 2 - Protococcophyceae; 3 - Desmidiales; 4 - Chrysomonadina; 5 - Bacillariophyceae; 6 - Cladocera; 7 - Protozoa; 8 - Insecta; 9 - Porifera; 10 - Ostracoda. По: Кордэ (1960). 


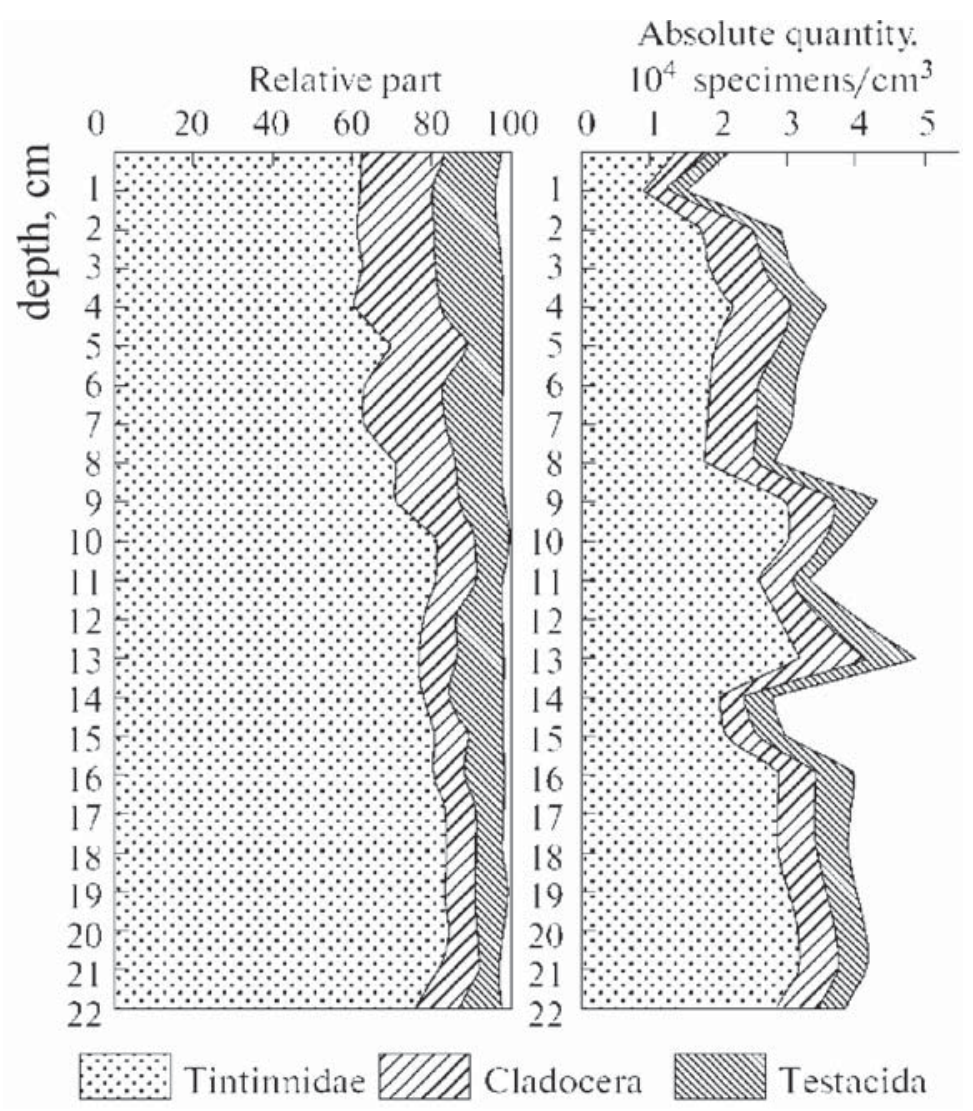

Fig. 2. Relative (left) and absolute (right) quantities of main groups of invertebrates in the core of bottom sediments $(0-23 \mathrm{~cm})$ from Kronostkoe Lake, Kamchatka Peninsula. After Smirnov et al. (2013).

Рис. 2. Относительные (слева) и абсолютные (справа) пропорции основных групп беспозвоночны в колонке донных отложений 0-23 см из Кроноцкого Озера, Камчатка. По: Смирнов и др. (2013).

Daphnia - domination in Lake Sevan, few in Lake Kaksoislammi (Sarmaja-Korjonen, 2002), littoral cladocerans - domination in Lake Herzensee (Hofmann, 2000), insignificant in the sediments of water reservoirs of Spain (Prat, Daroca, 1983).

Therefore, for the purpose of revealing the general type of a thanatocoenosis, it is highly advisable to begin routine treatment of cores of sediments with general quantitative analysis of all groups present: Cladocera, Ostracoda, Chironomidae, Chaoboridae, other insects, Turbellaria, Bryozoa, Spongia, Testacea, Tintinnidae. Investigaton of water bodies of various climatic zones is desired, as well of natural lakes, artificial reservoirs and ponds, technogenous lakes, etc.

The same is true of algological analysis.

The author thanks Dr R.J. Shiel for linguistic corrections on an earlier draft of the manuscript.

\section{References}

Harrison F.W. 1988. Utilization of freshwater sponges in paleolimnological studies // Palaeogeography, Palaeoclimatology, Palaeoecology. Vol.62. P.387-397.

Hofmann W. 2000. Response of the chydorid faunas to rapid climaic changes in four alpine lakes at different altitudes // Palaeogeography, Palaeoclimatology, Palaeoecology. Vol.150. P. 281-292. 
Karabanov E.B., Prokopenko A.A., Williams D.F., Khursevich G.K. 2000. A new record of Holocene climate change from the bottom sediments of Lake Baikal // Palaeogeography, Palaeoclimatology, Palaeoecology. Vol.156. P.211-224.

Kirillova I.V., Argant J., Lapteva E.G., Korona O.M., Van der Plicht J., Zinoviev E.V., Kotov A.A., Chernova O.F., Fadeeva E.O., Baturina O.A., Kabilov M.R., Shidlovskiy F.K., Zanina O.G. 2016. The diet and environment of mammoths in North-East Russia reconstructed from the contents of their feces // Quaternary International. Vol.406. P.147-161.

Korde N.V. 1960. [Biostratigraphy and typology of Russian sapropels]. Moscow: AN SSSR Press. 220 p. [In Russian]

Korde N.V. 1968. [Biostratigraphy of Sediments of Lake Kotokel] // Mezozoiskie i kainozoiskie ozera Sibiri [Mesozoic and Cenozoic Lakes of Siberia]. Moscow: Nauka. P.150-170 [in Russian].

Korosi J.B., Smol J.P. 2012. An illustrated guide to the identification of cladoceran subfossils from lake sediments in northeastern North America: part 2 - the Chydoridae // Journal of Paleolimnology. Vol.48. P.587-622.

Nazarova L., De Hoog V., Hoff U., Dirksen O., Diekmann B. 2013. Late Holocene climate and environmental changes in Kamchatka inferred from the subfossil chironomid record // Quaternary Science Reviews. Vol.67. P.81-92.

Nazarova L.B., Sapelko T.V., Kuznetsov D.D., Syrykh L.S. 2015. Palaeoecological and palaeoclimatical reconstructions of Holocene according chironomid anal- ysis of Lake Glubokoye sediments // Doklady Biological Sciences. Vol.460. P.57-60.

Prat N., Daroca V. 1983. Eutrophication processes in Spanish reservoirs as revealed by biological records // Hydrobiologia. Vol.103. P.153-158.

Sarmaja-Korjonen K. 2002. Multi-proxi data from Kaksoislammi Lake in Finland: dramatic changes in the late Holocene cladoceran assemblages // Journal of Paleolimnology. Vol.28. P.287-296.

Sapelko T.V., Smirnov N.N., Szeroczyńska K., Khasanov B.F., Bayanov N.G., Kuznetsov D.D., Antipushina Z.A. 2013. History of Lake Glubokoye (Moscow Region) from lake sediments // Doklady Earth Sciences. Vol.450. P.571-574.

Smirnov N.N. 1984. [Zoological analysis of ground of continental water bodies] // Itogi nauki i tekhniki. Moscow: VINITI. Vol.8. 145 p. [In Russian]

Smirnov N.N. 1999. The complex of crustacean remains in sediments of Lake Sevan, Armenia // Arthropoda Selecta. Vol.8. No.1. P.73-77.

Smirnov N.N. 2010. [Historic ecology of lake zoocoenoses]. Moscow: KMK Sci. Press. 225 p. [In Russian]

Smirnov N.N., Zharov A.A., Izvekova E.I., Markevich G.N. 2013. Changes in the zoocenosis of Lake Kronotskoe in the Late Holocene // Doklady Akademii Nauk. Vol.453. No.6. P.710-714.

Szeroczyńska K., Sarmaja-Korjonen K. 2007. Atlas of subfossil Cladocera from Central and Northern Europe. Ewiecie (Poland): Friends of the Lower Vistula Society. $83 \mathrm{p}$.

Responsible editor A.A. Kotov 